J. Product. \& Dev., 25(2): 247-261(2020)

\title{
EFFECT OF BULB CUTTING, STORAGE METHODS AND HOT WATER TREATMENT ON THE PROPAGATION OF Narcissus tazetta PLANTS
}

\section{E.Abd El Gayed}

Botanical Gardens Res. Depart., Hort. Res. Institute. ARC. Giza, Egypt.

e.mail.heshamelzaweily@gmail.com,abdelgayedm2020@gmail.com

\section{ABSTRACT}

The natural vegetative reproduction of narcissus plants under field conditions is very slow, as onion mothers produce few follicles, therefore increasing the production of the number of onions is one of the important things to improve the multiplication of narcissus bulbs. Therefore, during 2018 and 2019 seasons in the laboratory of Sakha Horticultural Research Station, Egypt, an experimental research was performed to study the effect of cutting methods of bulb (chipping and twin-scaling), storage temperatures (pre-cooling and no pre-cooling) and hot-water treatments (hot water and no hot water) on the propagation of Narcissus tazetta $c v$. "Ziva" bulbs.

The obtained results indicated that, chipping, pre-cooling and hot water treatments constantly affected the bulblet formation in both seasons and bulblet weight / chip in the first season only but had no effect on bulblets number. Chipping method improved all traits i.e. bulblet formation, fresh weight, circumference of bulblet and bulblets number / chip, leaves number and length as well as roots/chip. However, chipping caused in larger and fewer bulblets than twin-scaling. In the second season, pre-cooling was increased bulblet formation and both weight and circumference of bulblet and decreased number and length of leaves and roots. Hot-water treatments were increased bulblet formation but then number and length of leaves and roots were reduced.

Conclusively, it could be recommended to apply bulb cutting, pre cooling storage methods and hot water treatment on the bulbs to give the best results in propagation of Narcissus tazetta.

Keywords: Narcissus, cutting, storage methods and hot water treatment, bulb storage temperature 


\section{INTRODUCTION}

Narcissus, a genus of family Amaryllidaceae, involving of about 62 species, classed into 12 sections (Kington, 1989). These bulbs are well-known garden perennial, cut flowers and flowering potted plant. Additionally, to its horticultural values, the genus Narcissus provides various alkaloids, some of which exhibition pharmaceutical status (Bastida et al., 2011). Under field conditions the natural vegetative propagation rate of narcissus is very slow, with the mother bulb produce few daughter bulbs, nearly 1.6 bulbs/ year (Rees, 1992). Chipping and twin-scaling are two of traditional propagation techniques for rapidly propagating narcissus bulbs, enabling a rise from 1 to 1000 in 5-6.5 years instead of 15-25 years (Hanks, 1993). Depending on bulb size chipping bulbs are divided into 8 or 16 longitudinal segments, but these are not subdivided further (Kharrazi et al., 2107), while in twin-scaling are further divided by removing scale pieces in pairs by cutting through the attached basal plate. In this technique bulb is cut into 50 to 100 twin-scales, depending on its size (Zahng et al., 2013). Pre-treatment of bulbs may greatly affect the bulblets production from chipping and twin-scaling. Hanks, (1993) reported the successful use of hot-water treatment before narcissus bulb cutting to increase bulblet yields. Nevertheless, bulb storage temperature, has been reported to increase $\left(0-10\right.$ weeks at $5-30{ }^{\circ} \mathrm{C}$ ) (Hanks et al., 1986) or decrease (5 days at $35^{\circ} \mathrm{C}$ ) (Rees and Hanks, 1984) bulblets production, to be without effect (5 weeks $9{ }^{\circ} \mathrm{C}$ ) (Hanks and Rees, 1978).

Therefore, the objective of this study was to evaluate the effects of bulb cutting, storage methods and hot water treatment on the propagation of Narcissus tazetta to get a high yield of bulblets.

\section{MATERIALS AND METHODS}

During the two consecutive seasons of 2018 and 2019, an experimental was carried out in in the Laboratory of Sakha Horticultural Research Station, Egypt, to study the chipping and twin-scaling techniques and also to determine the effect of bulb storage temperature and hot-water treatment on propagation of Narcissus tazetta cv. "Ziva" to reach a high yield of bulblets. Bulbs of paperwhite narcissus were obtained from a commercial source Sperli- GmbH., and this source is foreign, but sources exist in Egypt.

In an experiment there were 8 treatments, consisting of all combinations 
of two hot water treatments (hot and non-hot) two pre-cutting storage temperatures (pre-cooled and non-pre-cooled bulbs) and two methods for propagation (chipping and twin-scaling). On July 1st, 2018 and 2019 seasons bulb were graded, singlenosed, round bulbs 12-14 cm in circumference were selected, washed, and separated into two groups of 48 bulbs each. In the first group the bulbs were given a hot water treatment at $43.5{ }^{\circ} \mathrm{C}$ for $3 \mathrm{~h}$, with $1.5 \%(\mathrm{v} / \mathrm{v})$ formalin, while the second one was drenched in a tap-water with $1.5 \%(\mathrm{v} / \mathrm{v})$ formalin (non-hot water). After drying, the bulbs were stored at ambient temperature $\left(27 \pm 3\right.$ and $20 \pm 3{ }^{\circ} \mathrm{C}$ day/ night, RH 67-70\%) until 6 weeks.

Relative humidity $(\mathrm{RH})$ prior to bulbs cutting time. Both groups were further divided into two subgroups of 24 bulbs each, the first subgroup was moved to a controlled chamber at a constant temperature of $9{ }^{\circ} \mathrm{C}, \mathrm{RH} 65-70 \%$ (pre-cooled bulbs), while the second one was left in the same ambient temperature (non-cooled bulbs) as described above until the start of the bulbs cutting treatments. On October $3^{\text {rd }}$ in both seasons, half of the bulbs of each group were propagated by chipping technique, while the other half was propagated by twin scaling. finally, each experiment included 12 bulbs ( 3 replication $\times 4$ bulbs).

After removing the outer brown truncated scales, and outer crust of basil plate, the top of bulbs was cut off for about $2.5 \mathrm{~cm}$. Meant for chipping, bulbs were longitudinally cut into eight equal sized segments. About twin-scale cuttings, segments of each bulb were divided into pairs of scales (twin-scales) by cutting through the basal plate, however the outer papery scales and the very small ones were discarded (stored to reject any outside the range 0.8-1.0 g) therefore each segment gave about 4 twin-scales (Hanks, 1985). Both chips and twin-scales were dipped in a fungicide solution with $1 \%$ captan $+0.4 \%$ benomyl (benlate) for 30 min. After dipping and draining, either 12 chips or 16 twin-scales were putted in polyethylene bags $(20 \times 30 \mathrm{~cm})$ filled with $500 \mathrm{ml}$ sterile vermiculite previously humidifier with $40 \mathrm{ml}$ sterile distilled water and sealed by ensuring air space at top. The bags were incubated in single layer in the dark at $20-22{ }^{\circ} \mathrm{C}$ and relative humidity of 70-80\% (Fig 1).

\section{The following data were recorded:}

After 15 weeks of incubation, the bulblet formation calculated as the percentage of chips and twin-scales with visible bulblet, number of bulblets per chip and twin-scale, number and length $(\mathrm{cm})$ of leaves and roots and circumference (cm) and weight $(\mathrm{g})$ of each bulblet were determined. 

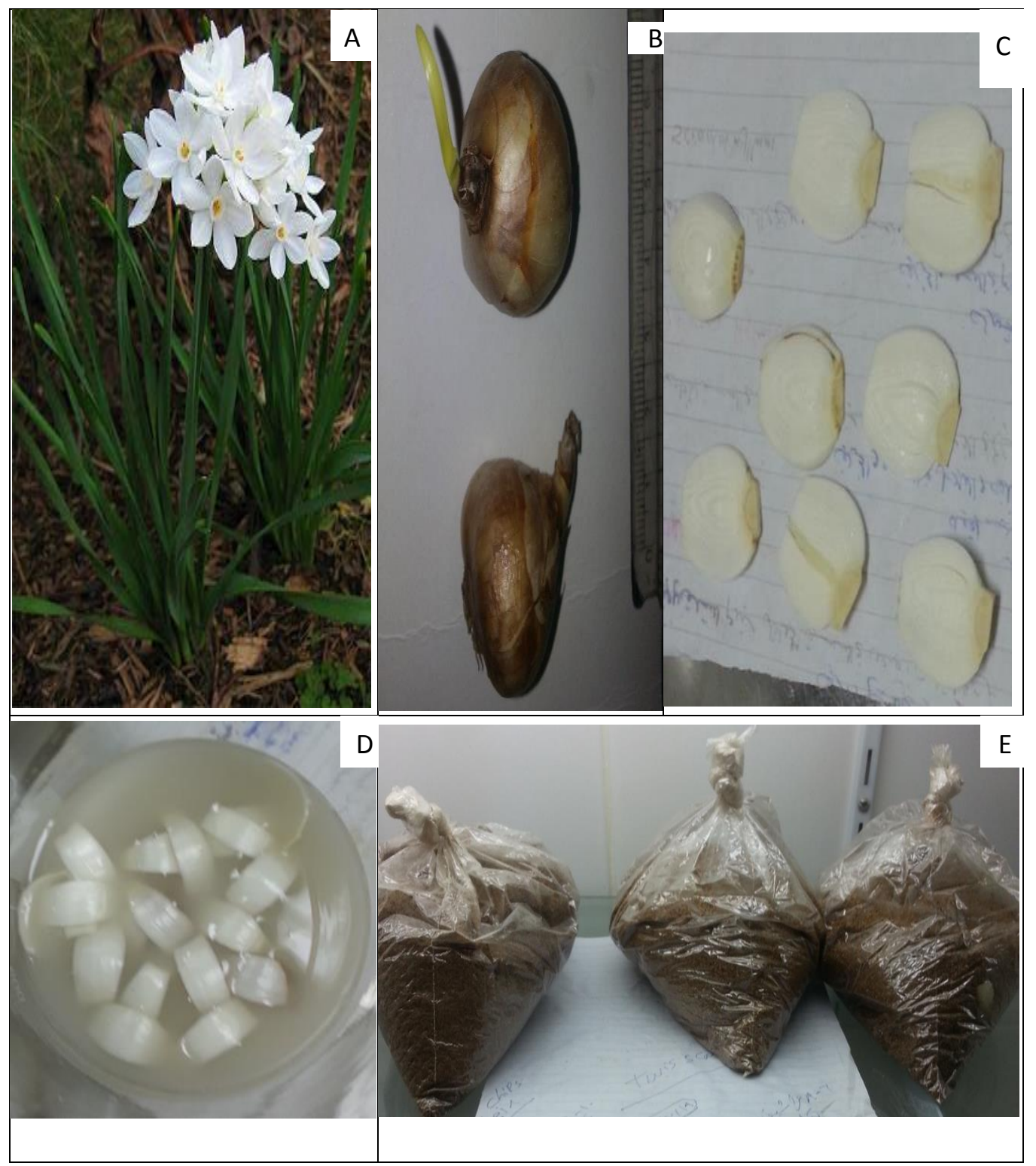

Figure (1). Flowering plant of Narcissus tazetta "Ziva (A), Bulb (B), Bulb chipping (C), Twin-scales treated with fungicide (D) Poly Ethelene bags in growth chamber (E). 


\section{Statistical Analysis:}

Data were analyzed by MSTATC computer software program (Bricker, 1991). The experimental design was factorial in a complete randomized with three replicates. The obtained data were subjected to analysis of variance according Snedecor and Cochran (1990). Duncan's multiple range test (Duncan, 1955) at 5\% level was used to compare the means.

\section{RESULTS AND DISCUSSION}

\section{1- Bulblet formation:}

Results were presented in Table (1) and Figure (2) revealed that there were significant differences between the treatments of propagation methods, prepropagating storage temperature and hot-water treatment on bulblet formation (\%). Chipping, pre-cooling and hot water treatment were increased bulblet formation in both seasons. Regarding the interaction between cutting methods and hot water treatments, and bulb storage temperature and cutting methods, hot water treatments and bulb storage were significant effect for bulblet formation percentage in the second season only. In this concern, the bulblet formation of the chips was $100 \%$ irrespective of bulb storage temperature and hot-water treatments were performed. In twin-scales, the highest bulblet formation (96.67\%) was obtained from bulbs given pre-cooling and hot water treatments. However, interaction between pre-cooling and hot water treatments significantly increased bulblet formation in the both seasons. Chipping method consistently affected the bulblet formation. The advantage of propagation by the chipping method are simpler and rapid multiplication that produces large quantities of good quality bulb with a relatively short period, but it is less productive (Hanks, 1993). Also, chips had more scales and wider basal plate than twin-scales, suggesting that a higher content of nutrients was stored in the chips (Zhang et al., 2013). The obtained results are similarly to the findings of Kharrazi et al., (2017) in Amaryllidaceae species and Nazari (2019) on Sternbergia lutea. Some species require a cold treatment for subsequent initiation and development of bulblet primordia and for rapid, synchronous growth (Khodorova and Boitel-Conti, 2013). However, the effect of previous bulb storage temperature on the performance of chips and twinscales propagation was reported in earlier studies on narcissus. Rees and Hanks (1984) found that pre-chipping storage temperature $\left(5\right.$ days at $35{ }^{\circ} \mathrm{C}$ ) reduced bulblet formation, whereas pre-cooling $\left(5\right.$ weeks at $\left.9{ }^{\circ} \mathrm{C}\right)$ alone or after a warm 
Table (1) Effect of cutting methods, bulb storage temperature and hot-water treatments on the percentage of narcissus bulblet formation during 2018 and 2019 seasons

\begin{tabular}{|c|c|c|c|c|c|c|c|c|c|}
\hline \multirow{4}{*}{ Treatments } & \multicolumn{9}{|c|}{ Bulblet formation (\%) } \\
\hline & \multicolumn{3}{|c|}{ Water } & & \multirow{2}{*}{\multicolumn{2}{|c|}{ Means }} & \multirow{2}{*}{\multicolumn{2}{|c|}{ Means }} & \multirow{3}{*}{$\begin{array}{l}\text { Means } \\
\text { cutting } \\
\text { methods }\end{array}$} \\
\hline & \multicolumn{2}{|r|}{ Non hwt* } & \multirow{2}{*}{$\begin{array}{c}\text { Hwt* }^{*} \\
\text { Non } \\
\text { cooled }\end{array}$} & \multirow[b]{2}{*}{ Cooled } & & & & & \\
\hline & $\begin{array}{l}\text { Non } \\
\text { cooled }\end{array}$ & Cooled & & & $\begin{array}{l}\text { Non } \\
\text { hwt* }\end{array}$ & Hwt* $^{*}$ & $\begin{array}{c}\text { Non } \\
\text { cooled }\end{array}$ & Cooled & \\
\hline \multirow{4}{*}{$\begin{array}{l}\text { Chipping } \\
\text { Twin-scaling } \\
\text { Mean }\end{array}$} & \multicolumn{9}{|c|}{ Season, 2018} \\
\hline & 80.33 & 88.20 & 87.03 & 91.00 & 84.27 & 89.10 & 83.68 & 89.68 & $86.68 \mathrm{a}$ \\
\hline & 69.27 & 76.17 & 79.50 & 82.50 & 72.72 & 81.00 & 74.38 & 79.33 & $76.86 \mathrm{~b}$ \\
\hline & $74.80 \mathrm{c}$ & $82.18 \mathrm{~b}$ & $83.27 \mathrm{~b}$ & $86.83 \mathrm{a}$ & $78.49 \mathrm{~b}$ & $85.05 \mathrm{a}$ & $79.03 \mathrm{~b}$ & $84.51 \mathrm{a}$ & \\
\hline \multirow{4}{*}{$\begin{array}{c}\text { Chipping } \\
\text { Twin-scaling } \\
\text { Mean }\end{array}$} & \multicolumn{9}{|c|}{ Season, 2109} \\
\hline & \multicolumn{2}{|c|}{$100.00 \mathrm{a} 100.00 \mathrm{a}$} & $100.00 \mathrm{a}$ & $100.00 \mathrm{a}$ & $100.00 \mathrm{a}$ & $100.0 \mathrm{a}$ & $100.00 \mathrm{a}$ & $100.0 \mathrm{a}$ & $00.00 \mathrm{a}$ \\
\hline & $78.33 d$ & $89.70 \mathrm{c}$ & $79.67 \mathrm{~d}$ & $96.67 \mathrm{~b}$ & $84.02 \mathrm{c}$ & $88.17 \mathrm{~b}$ & $79.00 \mathrm{c}$ & $93.18 \mathrm{~b}$ & $86.25 b$ \\
\hline & $89.17 \mathrm{c}$ & 94.85 & $89.83 \mathrm{c}$ & $98.33 \mathrm{a}$ & $92.01 \mathrm{~b}$ & $94.08 \mathrm{a}$ & $89.50 \mathrm{~b}$ & $96.59 \mathrm{a}$ & \\
\hline
\end{tabular}

Means within a column having the same letters are not significantly differences according to Duncan's multiple range test (DMRT). *Non hwt= Non hot water treatment Hwt $=$ Hot water treatment

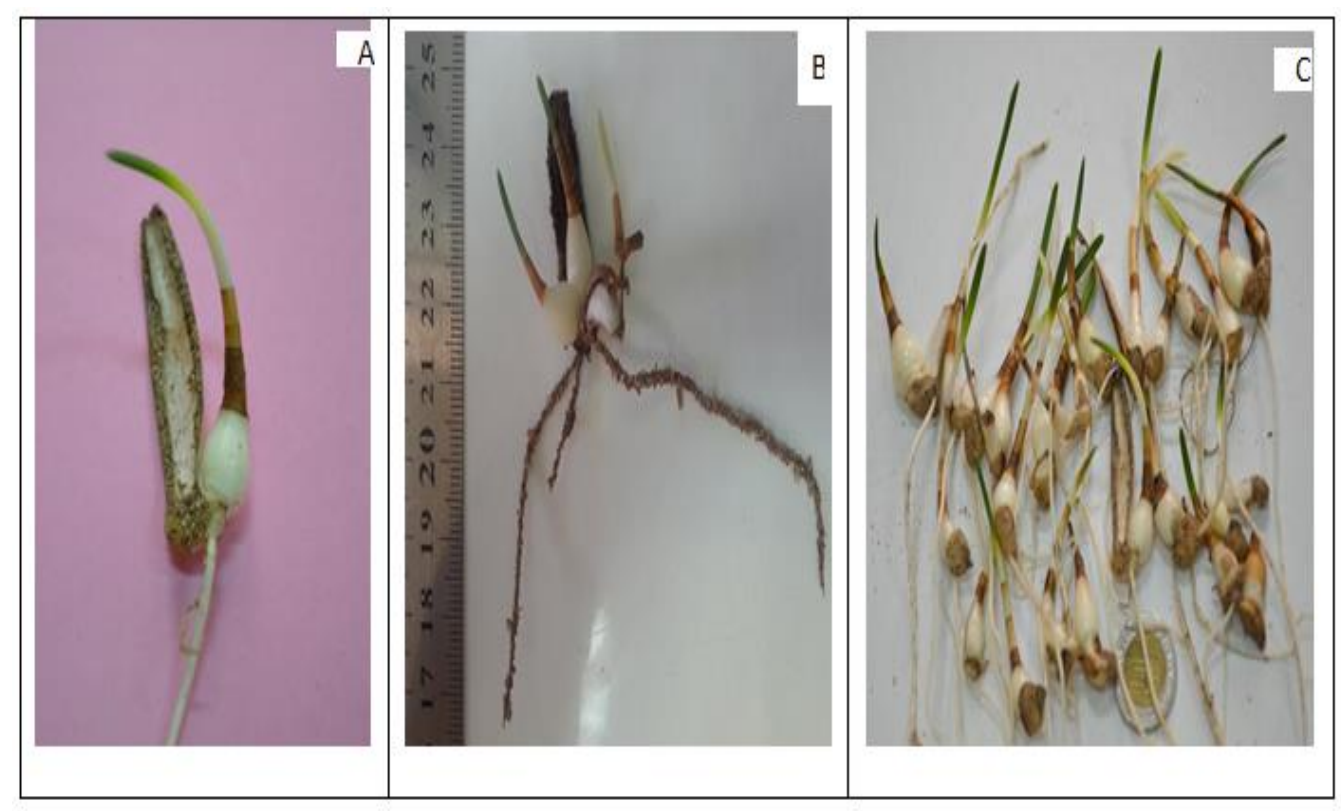

Figure (2). Bulblets growth from twin-scaling (A) and chipping (B), several bulblets production from twin-scaling $(\mathrm{C})$ 
storage did not affected bulblets formation. Hanks et al., (1986) showed that pretwin-scaling storage temperature $\left(0-10\right.$ weeks at a range of $\left.5-30{ }^{\circ} \mathrm{C}\right)$ produced bulblets in all cases, while the greatest bulblet formation was produced in bulbs stored at 15 and $30{ }^{\circ} \mathrm{C}$ for 6-7 weeks.

\section{2- Number of bulblets:}

The result were presented in Table (2) show that number of bulblets were increased with chipping method which recorded 1.59 and 1.42 while the twin scaling recorded 1.25 and 1.00 in both seasons, respectively. Also, there were non-significant effects of pre-propagating storage temperature, hot water treatment and all combination on bulblet numbers of chip and twin-scale in both seasons. The obtained results show similarity to findings by Zhang et al., (2013) on Hippeastrum vittatum cv. 'Kharrazi et al., (2017) on Hippeastrum johnsonii

Table (2). Effect of cutting methods, bulb storage temperature and hot-water treatments on number of narcissus bulblets during 2018 and 2019 seasons

\begin{tabular}{|c|c|c|c|c|c|c|c|c|c|}
\hline \multirow{4}{*}{ Treatments } & \multicolumn{9}{|c|}{ Number of bulblets } \\
\hline & \multicolumn{3}{|c|}{ Water } & & \multicolumn{2}{|c|}{ Mean } & \multicolumn{2}{|c|}{ Mean } & \multirow{2}{*}{$\begin{array}{l}\text { Mean } \\
\text { cutting } \\
\text { methods }\end{array}$} \\
\hline & \multicolumn{2}{|c|}{ Non hwt* } & Hwt* & \multirow[b]{2}{*}{ Cooled } & & & & & \\
\hline & $\begin{array}{c}\text { Non } \\
\text { Cooled }\end{array}$ & Cooled & $\begin{array}{c}\text { Non } \\
\text { cooled }\end{array}$ & & $\begin{array}{l}\text { Non } \\
\text { hwt }\end{array}$ & Hwt & $\begin{array}{l}\text { Non } \\
\text { cooled }\end{array}$ & Cooled & \\
\hline \multirow{4}{*}{$\begin{array}{l}\text { Chipping } \\
\text { Twin-scaling } \\
\text { Mean }\end{array}$} & \multicolumn{9}{|c|}{ Season, 2018} \\
\hline & 1.67 & 1.67 & 1.34 & 1.67 & 1.67 & 1.50 & 1.50 & 1.67 & $1.59 \mathrm{a}$ \\
\hline & 1.34 & 1.34 & 1.00 & 1.34 & 1.34 & 1.17 & 1.17 & 1.34 & $1.25 \mathrm{~b}$ \\
\hline & 1.50 & 1.50 & 1.17 & 1.50 & 1.50 & 1.33 & 1.34 & 1.50 & \\
\hline & \multicolumn{9}{|c|}{ Season, 2019} \\
\hline \multirow{3}{*}{$\begin{array}{c}\text { Chipping } \\
\text { Twin-scaling } \\
\text { Mean } \\
\end{array}$} & 1.67 & 1.34 & 1.34 & 1.34 & 1.50 & 1.34 & 1.50 & 1.34 & $1.42 \mathrm{a}$ \\
\hline & 1.00 & 1.00 & 1.00 & 1.00 & 1.00 & 1.00 & 1.00 & 1.00 & $1.0 \mathrm{~b}$ \\
\hline & 1.34 & 1.17 & 1.17 & 1.17 & $1.25 \mathrm{a}$ & $1.17 \mathrm{~b}$ & $1.25 \mathrm{a}$ & $1.17 \mathrm{~b}$ & \\
\hline
\end{tabular}

Means within a column having the same letters are not significantly differences according to Duncan's multiple range test (DMRT). *Non hwt= Non hot water treatment $\mathrm{Hwt}=$ Hot water treatment

\section{Circumference of bulblets:}

Chipping method significantly increased the circumference bulblet in the both seasons (Table 3), which recorded the greatest values 2.58 and $2.29 \mathrm{~cm}$, respectively. conversely, twin-scaling gave the lowest bulblet diameter 2.04 and $1.89 \mathrm{~cm}$, 
Table (3) Effect of cutting methods, bulb storage temperature and hot-water treatments on Circumference of Narcissus tazetta bulblets during 2018 and 2019 seasons

\begin{tabular}{|c|c|c|c|c|c|c|c|c|c|}
\hline & \multicolumn{9}{|c|}{ Circumference of bulblet (cm) } \\
\hline \multirow[t]{3}{*}{ Treatments } & & & & & \multirow{2}{*}{\multicolumn{2}{|c|}{ Mean }} & \multirow{2}{*}{\multicolumn{2}{|c|}{ Mean }} & \multirow{3}{*}{\begin{tabular}{|c|} 
Mean \\
cutting \\
methods
\end{tabular}} \\
\hline & & $\mathbf{w t}^{*}$ & Hwt* & & & & & & \\
\hline & Non c & ooled & $\begin{array}{c}\text { Non } \\
\text { cooled }\end{array}$ & Cooled & $\begin{array}{c}\text { Non } \\
\text { hwt }\end{array}$ & Hwt & $\begin{array}{l}\text { Non } \\
\text { Cooled }\end{array}$ & Cooled & \\
\hline & \multicolumn{9}{|c|}{ Season, 2018} \\
\hline Chipping & 2.34 & 2.54 & 2.47 & 2.96 & $2.43 \mathrm{~b}$ & $2.72 \mathrm{a}$ & $2.40 \mathrm{~b}$ & $2.75 \mathrm{a}$ & $2.58 \mathrm{a}$ \\
\hline Twin-scaling & 2.14 & 2.21 & 1.94 & 1.87 & $2.17 \mathrm{c}$ & $1.90 \mathrm{~d}$ & $2.04 \mathrm{c}$ & $2.04 \mathrm{c}$ & $2.04 \mathrm{~b}$ \\
\hline Mean & 2.24 & 2.37 & 2.20 & 2.42 & 2.30 & 2.31 & $2.22 \mathrm{~b}$ & $2.39 \mathrm{a}$ & \\
\hline \multirow{4}{*}{$\begin{array}{c}\text { Chipping } \\
\text { Twin-scaling } \\
\text { Mean }\end{array}$} & \multicolumn{9}{|c|}{ Season, 2019} \\
\hline & 2.30 & 2.73 & 2.00 & 2.13 & 2.51 & 2.07 & 2.15 & 2.43 & $2.29 \mathrm{a}$ \\
\hline & 2.00 & 1.80 & 1.97 & 1.80 & 1.90 & 1.88 & 1.98 & 1.80 & $1.89 \mathrm{~b}$ \\
\hline & 2.15 & 2.26 & 1.98 & 1.97 & 2.20 & 1.98 & 2.07 & 2.11 & \\
\hline
\end{tabular}

Means within a column having the same letters are not significantly differences according to Duncan's multiple range test (DMRT). $*$ Non hwt $=$ Non hot water treatment $\mathrm{Hwt}=$ Hot water treatment.

respectively in both seasons.

Regarding, the combination between pre-cooled and chipping gave markedly the wider circumference of bulblet $(2.75 \mathrm{~cm})$. Whereas, the bulbs which were stored at ambient temperature and propagated with twin-scaling gave the lowest value $(2.04 \mathrm{~cm})$ in the first season. Referring to the interaction between propagation methods and hot water, chipping method $\mathrm{x}$ hot water produced a wider maximum circumference of bulblet $(2,72 \mathrm{~cm}$ in first season), whereas the twin-scaling $\mathrm{x}$ hot water gave the least value $(1.90 \mathrm{~cm})$ in the first season. These results are in conformity with those of Nazari (2019) investigated the effects of some plant growth regulators on induction and on Sternbergia lutea and Seyidoglu and Zencirkiran (2008) showed that chipping technique could be used for bulbils production in Sternbergia lutea (L.) "Ker-Gawl. Ex Sprengel". The highest bulbils formation obtained from the bulbs having a circumference $11-12 \mathrm{~cm}$. In the same line, Hanks (2015) on narcissus.

\section{Fresh weight of bulblets:}

Results were presented in Table (4) revealed that chipping method drastically increased fresh weight in both seasons, while pre-cooling significantly 
Table (4) Effect of cutting methods, bulb storage temperature and hot-water treatments on fresh weight of Narcissus tazetta bulblets during 2018 and 2019 seasons

\begin{tabular}{|c|c|c|c|c|c|c|c|c|}
\hline \multirow{4}{*}{ Treatments } & & & \multicolumn{6}{|c|}{ Fresh weight of bulblet (g) } \\
\hline & Water & \multirow{2}{*}{ Hwt* } & \multirow[b]{3}{*}{ Cooled } & & & \multirow{3}{*}{$\begin{array}{l}\text { Mean } \\
\text { cutting } \\
\text { methods }\end{array}$} \\
\hline & \multirow[b]{2}{*}{$\begin{array}{l}\text { Non } \\
\text { Cooled } \\
\text { Cooled }\end{array}$} & & & \multicolumn{2}{|c|}{ Mean } & \multicolumn{2}{|c|}{ Mean } & \\
\hline & & $\begin{array}{l}\text { Non } \\
\text { cooled }\end{array}$ & & Non hwt & Hwt & $\begin{array}{l}\text { Non } \\
\text { Cooled }\end{array}$ & Cooled & \\
\hline \multirow{4}{*}{$\begin{array}{l}\text { Chipping } \\
\text { Twin-scaling } \\
\text { Mean }\end{array}$} & \multirow{4}{*}{$\begin{array}{|cl|}0.33 \mathrm{~b} & 0.34 \mathrm{~b} \\
0.17 \mathrm{~d} & 0.21 \mathrm{~cd} \\
0.25 & 0.27\end{array}$} & \multicolumn{6}{|c|}{ Season, 2018} & \\
\hline & & \multirow{3}{*}{$\begin{array}{c}0.27 \mathrm{bc} \\
0.16 \mathrm{~d} \\
0.21\end{array}$} & \multirow{3}{*}{\begin{tabular}{|c}
$0.43 \mathrm{a}$ \\
$0.15 \mathrm{~d}$ \\
0.29
\end{tabular}} & 0.34 & 0.35 & $0.29 \mathrm{~b}$ & $0.39 \mathrm{a}$ & $0.34 \mathrm{a}$ \\
\hline & & & & 0.19 & 0.16 & $0.17 \mathrm{c}$ & $0.18 \mathrm{c}$ & $0.17 \mathrm{~b}$ \\
\hline & & & & 0.26 & 0.25 & $0.23 \mathrm{~b}$ & $0.28 \mathrm{a}$ & \\
\hline \multirow{4}{*}{$\begin{array}{c}\text { Chipping } \\
\text { Twin-scaling } \\
\text { Mean } \\
\end{array}$} & \multicolumn{8}{|c|}{ Season, 2019} \\
\hline & $\begin{array}{ll}0.36 & 0.38\end{array}$ & 0.29 & 0.38 & 0.37 & 0.34 & 0.33 & 0.38 & $0.35 \mathrm{a}$ \\
\hline & $\begin{array}{ll}0.27 & 0.24 \\
\end{array}$ & 0.28 & 0.22 & 0.26 & 0.25 & 0.28 & 0.23 & $0.25 \mathrm{~b}$ \\
\hline & $\begin{array}{ll}0.32 & 0.31 \\
\end{array}$ & 0.29 & 0.29 & 0.31 & 0.29 & 0.31 & 0.26 & \\
\hline
\end{tabular}

Means within a column having the same letters are not significantly differences according to Duncan's multiple range test (DMRT). *Non hwt= Non hot water treatment

Hwt $=$ Hot water treatment

improved fresh weight of bulblet in the first season. Meanwhile, hot-water treatment had no effects in both seasons. The combination treatment of chipping method x pre-cooled bulbs was produced the heaviest weight of bulblet. The combined effect of cutting method, pre- propagation storage temperature and hot water were exhibited significant influence on fresh weight of bulblet in the first season. However, the highest bulblet weight $(0.43 \mathrm{~g})$ was obtained from the combination treatment of chipping $\mathrm{x}$ pre- cooling $\mathrm{x}$ hot water comparing with the lowest value $(0.15 \mathrm{~g})$ was obtained by the combined treatment of twin-scaling $\mathrm{x}$ pre-cooling $\mathrm{x}$ hot water. The obtained results are in accordance with those of Fenlon et al., (1990) on narcissus demonstrated that there was a linear relationship between bulb weight per chip and initial chip weight, this gives the possibility of achieving target bulb weights after the first year by adjusting the cutting rate relative to initial bulb grade. Also, bulb weight/cutting rate combinations were identified which approached the ideal of yielding just one, uniformly large bulb per propagule. In the same line, Jamil et al., (2014) on hippeastrum and Hanks (2015) on narcissus. 


\section{5-Number of leaves/ bulblet:}

Results presented in Table (5) showed that chipping method statically increased number of leaves when compared with the twin- scaling method in 2018 and 2019 seasons. In the second season pre-propagation storage temperature, precooling treatment significantly decreased the number of leaves/ bulblet when compared with the non-pre-cooled bulbs. Additionally, hot water treatment significantly decreased the number of leaves per bulblet compared with the nonhot water. As for, the interaction within pre-propagating storage temperature and hot-water treatment showed that the number of leaves per bulblet in cooling-stored bulbs were declined with hot-water treatment as gave 1.64 against 2.14 for the non-hot water in first season. These previously mentioned results seemed to agree with those reported by Hanks, (1991) on Narcissus.

Table (5) Effect of cutting methods, bulb storage temperature and hot-water treatments on Number of leaves of Narcissus tazetta bulblets during 2018 and 2019 seasons

\begin{tabular}{|c|c|c|c|c|c|c|c|c|c|}
\hline \multirow{5}{*}{ Treatments } & \multicolumn{9}{|c|}{ Number of leaves per bulblet } \\
\hline & \multicolumn{2}{|c|}{ Water } & \multirow[b]{2}{*}{ Hwt* } & & \multicolumn{2}{|c|}{ Mean } & \multicolumn{2}{|c|}{ Mean } & \multirow{4}{*}{$\begin{array}{l}\text { Mean } \\
\text { cutting } \\
\text { methods }\end{array}$} \\
\hline & \multirow{3}{*}{\multicolumn{2}{|c|}{\begin{tabular}{|l|}
\multicolumn{2}{|c}{ Non hwt* } \\
Non \\
Cooled \\
Cooled \\
\end{tabular}}} & & \multirow{3}{*}{ Cooled } & & & & & \\
\hline & & & \multirow{2}{*}{ Non } & & \multirow{2}{*}{ Non hwt } & \multirow{2}{*}{ Hwt } & \multicolumn{2}{|l|}{ Non } & \\
\hline & & & & & & & Cooled & Cooled & \\
\hline & \multicolumn{9}{|c|}{ Season, 2018} \\
\hline Chipping & 2.00 & 2.47 & 2.00 & 1.90 & 2.24 & 1.95 & 2.00 & 2.18 & $2.09 a$ \\
\hline Twin-scaling & 1.70 & 1.80 & 1.63 & 1.36 & 1.75 & 1.50 & 1.67 & 1.58 & $1.63 \mathrm{~b}$ \\
\hline \multirow[t]{2}{*}{ Mean } & $1.85 \mathrm{~b}$ & $2.14 a$ & $1.82 \mathrm{bc}$ & $1.64 \mathrm{c}$ & $1.99 a$ & $1.73 b$ & 1.84 & 1.88 & \\
\hline & \multicolumn{9}{|c|}{ Season, 2019} \\
\hline \multirow{3}{*}{$\begin{array}{c}\text { Chipping } \\
\text { Twin-scaling } \\
\text { Mean }\end{array}$} & 1.81 & 1.18 & 1.87 & 1.60 & 1.50 & 1.74 & 1.84 & 1.40 & $1.62 a$ \\
\hline & 1.53 & 1.50 & 1.50 & 1.47 & 1.50 & 1.48 & 1.52 & 1.47 & $1.49 b$ \\
\hline & 1.67 & 1.34 & 1.68 & 1.54 & 1.50 & 1.61 & $1.68 \mathrm{a}$ & $1.44 \mathrm{~b}$ & \\
\hline
\end{tabular}

Means within a column having the same letters are not significantly differences according to Duncan's multiple range test (DMRT). *Non hwt= Non hot water treatment

Hwt $=$ Hot water treatment

\section{6- Root number and length/ bulblet:}

Results presented in Table (6) revealed that number of roots was increased under chipping method comparing with the twin- scaling method in both seasons. Likewise, pre-cooling treatment significantly decreased the number of roots / bulblet (1.59) when compared with the non-pre- cooled bulbs (1.74) in the second 
season. Concerning the hot water treatment significantly decreased the number of roots per bulblet (1.85) compared with the non hwt (2.06) in the first season. There was non-significant effect of cutting method, pre-cooling, hot water treatment and all combinations on number of roots/ bulblet in both seasons of study. Regarding to root length the results presented in Table (7) showed that there were significant differences for the effect of cutting methods in both seasons, pre-propagation storage temperature in the second season, hot water treatment in the first one and interaction between cutting methods and pre-propagation storage temperature in the second season, on length of roots/ bulblet. Chipping method significantly increased the length of roots per bulblet in both seasons $(2.65$ and $1.84 \mathrm{~cm}$, respectively) compared with the twin-scaling (1.84 and $1.38 \mathrm{~cm}$ respectively). While pre- cooling treatment in the second season and hot water treatment in the first season significantly decreased the length of roots. The combined effect of cutting methods and hot water, gave the shortest roots/ bulblet of the chipping and twin scaling methods (2.19 and $1.83 \mathrm{~cm}$, respectively) in the first season. However, roots were longest in non-hot water bulbs and chipping $(3.11 \mathrm{~cm})$. Such findings are in harmony with those reported by Zhang et al., (2013) on hippeastrum, Seyidoglu and Zencirkiran (2008) on Sternbergia lutea.

Table (6) Effect of cutting methods, bulb storage temperature and hot-water treatments on Number of roots of Narcissus tazetta bulblets during 2018 and 2019 seasons

\begin{tabular}{|c|c|c|c|c|c|c|c|c|c|}
\hline \multirow{4}{*}{ Treatments } & & & & \multicolumn{6}{|c|}{ Number of roots per bulblet } \\
\hline & \multicolumn{2}{|c|}{ Water } & & & \multicolumn{2}{|c|}{ Mean } & \multicolumn{2}{|l|}{ Mean } & \multirow{3}{*}{$\begin{array}{l}\text { Mean } \\
\text { cutting } \\
\text { methods }\end{array}$} \\
\hline & \multicolumn{2}{|c|}{ Non hwt* } & Hwt* & & & & & & \\
\hline & $\begin{array}{l}\text { Non } \\
\text { cooled }\end{array}$ & Cooled & $\begin{array}{l}\text { Non } \\
\text { cooled }\end{array}$ & Cooled & Non hwt & Hwt & Non cooled & Cooled & \\
\hline \multirow[t]{2}{*}{ Chipping } & \multicolumn{9}{|c|}{ Season, 2018} \\
\hline & 2.70 & 2.34 & 2.30 & 2.00 & 2.52 & 2.15 & 2.50 & 2.17 & $2.34 \mathrm{a}$ \\
\hline Twin-caling & 1.70 & 1.52 & 1.58 & 1.50 & 1.61 & 1.54 & 1.65 & 1.51 & $1.58 \mathrm{~b}$ \\
\hline Mean & 2.20 & 1.93 & 1.94 & 1.75 & $2.06 \mathrm{a}$ & $1.85 \mathrm{~b}$ & 2.07 & 1.84 & \\
\hline \multirow{4}{*}{$\begin{array}{c}\text { Chipping } \\
\text { Twin-caling } \\
\text { Mean }\end{array}$} & & & & \multicolumn{6}{|c|}{ Season, 2019} \\
\hline & 1.81 & 1.67 & 1.87 & 1.87 & 1.74 & 1.87 & 1.84 & 1.77 & $1.80 \mathrm{a}$ \\
\hline & 1.74 & 1.32 & 1.57 & 1.50 & 1.53 & 1.54 & 1.65 & 1.41 & $1.53 \mathrm{~b}$ \\
\hline & 1.77 & 1.49 & 1.72 & 1.68 & 1.63 & 1.70 & $1.74 \mathrm{a}$ & $1.59 \mathrm{~b}$ & \\
\hline
\end{tabular}

Means within a column having the same letters are not significantly differences according to Duncan's multiple range test (DMRT). *Non hwt= Non hot water treatment Hwt $=$ Hot water treatment 
Table (7) Effect of cutting methods, bulb storage temperature and hot-water treatments on roots length of Narcissus tazetta bulblets during 2018 and 2019 seasons

\begin{tabular}{|c|c|c|c|c|c|c|c|c|c|}
\hline \multirow{4}{*}{ Treatments } & \multicolumn{9}{|c|}{ Length of roots / bulblet $(\mathrm{cm})$} \\
\hline & \multicolumn{4}{|c|}{ Water } & \multirow{2}{*}{\multicolumn{2}{|c|}{ Mean }} & \multirow{2}{*}{\multicolumn{2}{|c|}{ Mean }} & \multirow{3}{*}{$\begin{array}{l}\text { Mean } \\
\text { cutting } \\
\text { methods }\end{array}$} \\
\hline & \multirow{2}{*}{\multicolumn{2}{|c|}{$\begin{array}{l}\text { Non hwt* } \\
\text { Non } \\
\text { cooled Cooled }\end{array}$}} & \multirow{2}{*}{\begin{tabular}{|c|} 
Hwt* \\
Non cooled
\end{tabular}} & \multirow[b]{2}{*}{ Cooled } & & & & & \\
\hline & & & & & Non hwt & Hwt & \multicolumn{2}{|c|}{ Non cooled Cooled } & \\
\hline \multirow[b]{2}{*}{$\begin{array}{c}\text { Chipping } \\
\text { Twin-scaling } \\
\text { Mean }\end{array}$} & \multicolumn{9}{|c|}{ Season, 2018} \\
\hline & $\begin{array}{r}3.24 \\
1.60 \\
2.42 \mathrm{a}\end{array}$ & $\begin{array}{r}2.98 \\
2.08 \\
2.53 \mathrm{a}\end{array}$ & $\begin{array}{l}2.42 \\
2.15 \\
2.28 \mathrm{a}\end{array}$ & $\begin{array}{r}1.98 \\
1.50 \\
1.74 b\end{array}$ & $\begin{array}{l}3.11 \mathrm{a} \\
1.84 \mathrm{~b} \\
2.47 \mathrm{a}\end{array}$ & $\begin{array}{l}2.19 \mathrm{~b} \\
1.83 \mathrm{~b} \\
2.02 \mathrm{~b}\end{array}$ & $\begin{array}{c}2.83 \\
1.88 \\
2.35 \mathrm{a}\end{array}$ & $\begin{array}{r}2.48 \\
1.79 \\
2.14 \mathrm{~b}\end{array}$ & $\begin{array}{l}2.65 \mathrm{a} \\
1.84 \mathrm{~b}\end{array}$ \\
\hline \multirow{4}{*}{$\begin{array}{c}\text { Chipping } \\
\text { Twin-scaling } \\
\text { Mean }\end{array}$} & \multicolumn{9}{|c|}{ Season, 2019} \\
\hline & 2.00 & 1.40 & 2.00 & 1.97 & 1.70 & 1.98 & 2.00 & 1.68 & $1.84 \mathrm{a}$ \\
\hline & 1.57 & 1.24 & 1.54 & 1.17 & 1.40 & 1.35 & 1.55 & 1.20 & $1.38 \mathrm{~b}$ \\
\hline & 1.78 & 1.32 & 1.77 & 1.57 & 1.55 & 1.67 & 1.78 & 1.44 & \\
\hline
\end{tabular}

Means within a column having the same letters are not significantly differences according to Duncan's multiple range test (DMRT). *Non hwt= Non hot water treatment Hwt $=$ Hot water treatment

Conclusively, it can be concluded that in chipping method the segments produce larger but fewer bulblets/ bulb than those produce by twin-scaling and may reach flowering size more rapidly.

However, hot-water treatment, pre-cooling of bulbs before twin-scaling enhanced the bulblet formation. Though relatively labour-intensive, twin-scaling dose have an imperative role to play in bulking-up schemes, because of its possibly larger multiplication rate. Conversely, in chipping method, size of parent bulb and number of chips/ bulbs must be taken into contemplation.

\section{REFERENCES}

Bastida, J., S. Berkov.; L. Torras; N. B. Pigni.; J. P. De Andrade; V. Martinoz; C. Codina and F. Viladomat (2011). Chemical and Biological Aspects of Amaryllidaceae Alkaloids. - In: Munoz-Torrero, D. (ed.) Recent Advances in Pharmaceutical Sciences. Transworld Research Network, Kerala. 65-100. 
Bricker, B. (1991) MSTATC: A Micro Computer Program from the Design Management and Analysis of Agronomic Research Experiments. Michigan State.

Duncan, B. D. (1955). Multiple range and multiple F-test. Biometrics, 11:1-42.

Fenlon, J. S.; S. K. Jones.; G. R. Hanks and F. A. Langton (1990). Bulb yields from Narcissus chipping and twin-scaling. - J. Hortic. Sci. 65: 441-450.

Hanks, G. R. and A. R. Rees (1978). Factors affecting twin-scale propagation of narcissus. Scientia Horticulture. 9: 399-411.

Hanks, G. R. (2015). Pre-warming of narcissus, prior to hot-water treatment, in Lincolnshire. narcissus Growers Workshops Redruth and Spalding in association with CABGA \& EGBA.

Hanks, G. R. (1985). Factors affecting yields of adventitious bulblets during propagation of narcissus by the twin-scaling technique. J. Hortic. Sci., 60: 531-543.

Hanks, G. R. (1991). Pre-Warming of Narcissus, prior to Hot-Water Treatment, in Lincolnshire. Hort. Development Council, Petersfield. HDC Project BOFIS. HRI Project 30284.

Hanks, G. R. (1993). Narcissus. - In: De Hertogh, A. A., Le Nard, M. (eds.) The Physiology of Flowering Bulbs. Elsevier Sci. Pub., Amsterdam., 463-558.

Hanks, G. R., G. Shaik and S. K. Jones (1986). Bulblet production in Narcissus: the effect of temperature and duration of storage on bulb unit development and subsequent propagation by twin-scaling. Ann. Appl. Biol. , 109: 417-425.

Jamil M. K., M. M. Rahman and M. M. Rahman (2014). Effect of bulb cutting and pot medium on propagation of hippeastrum (Hippeastrum hybridum Hort.). Journal of Ornamental Plants, 4 (3): 123-132.

Kharrazi, M., A. Tehranifar; H. Nemati and A. Bagheri (2017): Vegetative propagation of amaryllis (Hippeastrum $\times$ johnsonii) by different cutting methods. Horticultural Science and Technology, 35(3): 373-380.

Khodorova, N. V and M. Boitel-Conti (2013). The role of temperature in the growth and flowering of geophytes. - Plants 2: 699-711.

Kington, S. (1989). The International Daffodil Checklist. Royal Horticultural Society, London.

Nazari, F. (2019). Propagation of endemic and endangered sternbergia lutea with a high ornamental value by bulb chipping and plant growth regulators. Acta Sci. Pol. Hortorum Cultus, 18(2), 123-131. 
Rees A. R. and G. R. Hanks (1984). Storage treatments for very early forcing of Narcissus. J. Hort. Sci., 59(2):229-239.

Rees, A. R. (1992). Ornamental Bulbs, Corms, and Tubers. CAB International, Wallingford, UK.

Seyidoglu, $\mathbf{N}$ and $\mathbf{M}$. Zencirkiran (2008). Vegetative propagation of Sternbergia lutea (L) Ker Gawl. ex Sprengel (Winter Daffodil) By chipping techniques. J. Biol. Sci., 8: 966-969.

Snedecor, G. W. and W.G. Cochran (1990). Statistical Methods. $7^{\text {th }}$ Ed. Iowa State Univ. Press. Ames., Iowa, USA., 593 pp.

Zhang W., Song L., J. A. Teixeira da Silva and H. M. Sun (2013). Effects of temperature, plant growth regulators and substrates and changes in carbohydrate content during bulblet formation by twin scale propagation in Hippeastrum vittatum 'Red lion'. Scientia Horticulture, 160: 230-237.

\section{تأثير طرق تقطيع وتخزين الابصال والمعاملة بالماء الساخن على المائ اكثار نباتات النرجس البلدي}

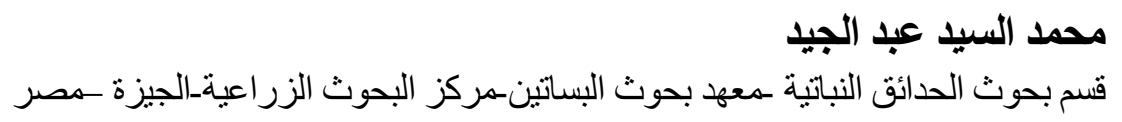

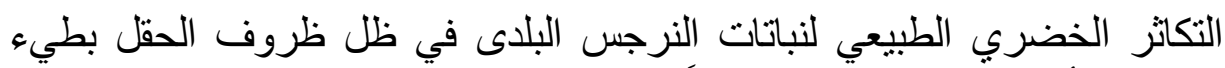

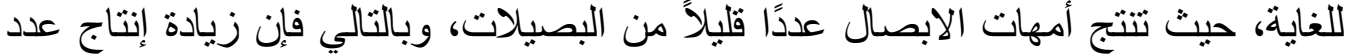

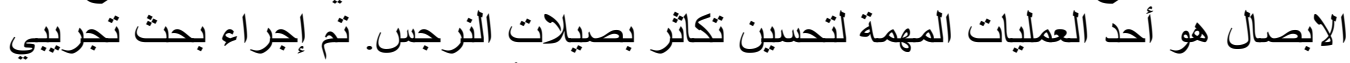

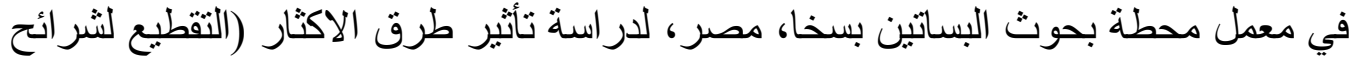

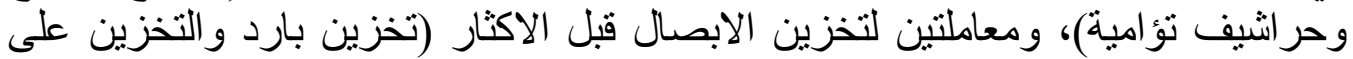

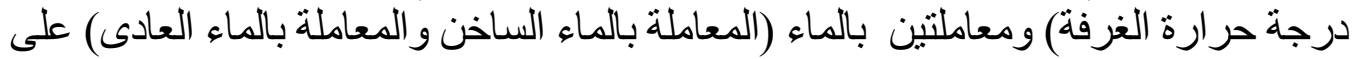

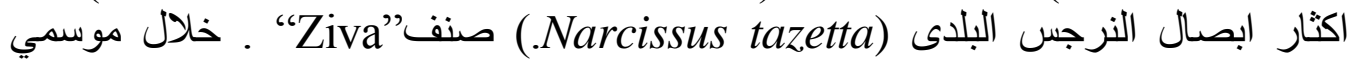


أثشارت النتائج التي تم الحصول عليها إلى : أن معاملات التقطيع و التخزين البارد للابصال

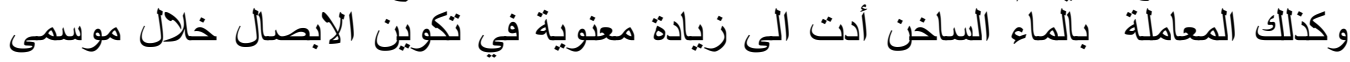

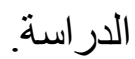

حسّنت طريقة تقطيع الابصال من صفات تكوين البصيلات و الوزن الطازج ومحيط البصيلة وعدد الاوراق و الجذور لكل بصيلة.

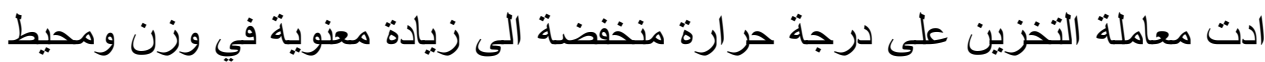

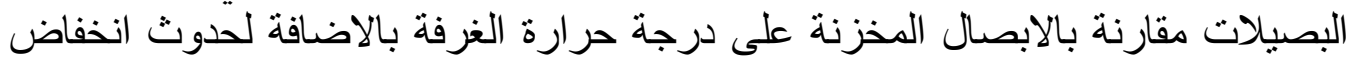

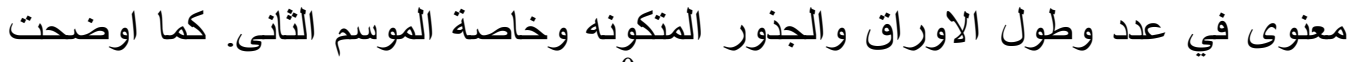

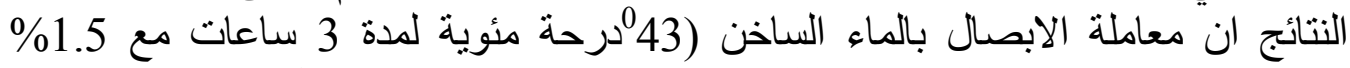

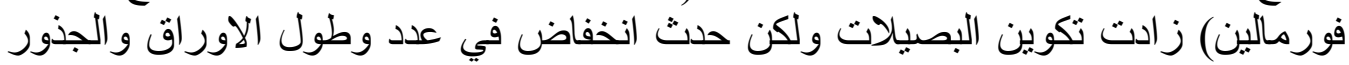
اللبصيلات.

التوصية: بمكن بتطبيق معاملات تقطيع الابصال، والتخزين المبرد وكذلك المعامله بالماء

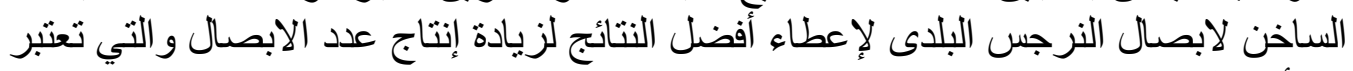
من أحد العمليات المهمة لتحسين تكاثر بصيلات النرجل النرجس. 